\title{
ON THE EVALUATION OF BRAZILIAN LANDLINE TELEPHONE SERVICES COMPANIES
}

\author{
José Virgílio Guedes de Avellar \\ Alexandre Olympio Dower Polezzi \\ Armando Zeferino Milioni * \\ Divisão de Engenharia Mecânica-Aeronáutica \\ Instituto Tecnológico de Aeronáutica \\ São José dos Campos - SP \\ E-mails: avellar@mec.ita.br \\ ale.ita@uol.com.br \\ milioni@mec.ita.br \\ * Corresponding author/autor para quem as correspondências devem ser encaminhadas \\ Received September 2001; accepted October 2002 after one revision.
}

\begin{abstract}
In this work we investigate the relative efficiency of 34 Brazilian Landline Telephone Service companies using Data Envelopment Analysis with weight constraints in the input and output variables. We formulate two different models that take into account the performance of the companies with respect to the criteria defined by Brazilian National Agency of Telecommunications (ANATEL). We also illustrate the potential of efficiency improvement through the simulation of corporate Merger.
\end{abstract}

Keywords: DEA, telecommunications, weight constraints.

\section{Resumo}

Neste trabalho investigamos a eficiência relativa das 34 operadoras do Setor de Telefonia Fixa Comutada através da utilização de Análise de Envoltória de Dados com restrições nos pesos das variáveis de input e output. Formulamos dois modelos distintos que levam em consideração o desempenho das empresas quanto aos critérios definidos pela Agência Nacional de Telecomunicações (ANATEL). Também ilustramos o potencial de melhoria de eficiência através de simulações de fusões corporativas (Merger).

Palavras-chave: DEA, telecomunicações, restrições nos pesos. 


\section{Introduction}

The privatization of the Landline Telephone Services in Brazil and the opening of the market for international operators caused significant changes in the profile of the companies offering these services, since they are now operating in a highly competitive environment as opposed to what happened in the past.

The Brazilian National Agency of Telecommunications (ANATEL) maintains an intense control of those companies, rewarding good results - for instance, through the permission of access to competition in new operation areas - and punishing through fines the nonaccomplishment of the established goals.

In July of 1998 ANATEL settled goals to be measured on the last day of the up coming 5 years. Goals were settled for each company with regard to the Quality of the services provided (see "Plano Geral de Metas de Qualidade para o STFC", 1998) and the so called "Universality" issue - which says respect to all citizens right to wide access to telecommunications services (see "Plano Geral de Metas de Universalização para o STFC", 1998).

This work fits in the context of ANATEL's continuous effort in evaluating the performance of 34 companies that are regular operators in the Brazilian Landline Telephone Service (called STFC - Serviços de Telefonia Fixa Comutada - operators). With a similar purpose Milioni developed for ANATEL (Milioni, 2001-a) an AHP model (Analytical Hierarchical Process) that took in consideration specific aspects of Universality, Quality and Fees associates to each company. Milioni concluded that for the comparison of the companies the Fee aspect was practically irrelevant, since all companies practice the maximum allowed fee except for very specific schedules of the day or punctual promotions and loyalty contracts. Although interesting, the results of Milioni, as a consequence of the technique used in his work, are limited to the ranking of the analyzed companies.

The methodology we use in this work is Data Envelopment Analysis (DEA), a nonparametric method developed to evaluate the relative efficiency of different entities of a common nature. Based on linear programming techniques, DEA is considered a robust tool for the evaluation of relative efficiencies as well as for the establishment of goals (or benchmarks) for the entities out of the efficiency border (or envelope). The analyzed entities or DMU's (for Decision Making Units) are compared under Farrel's concept of efficiency (Farrel et al., 1962), that consists of a ratio of the weighted sum of the outputs y over the weighted sum of the inputs $\mathrm{x}$ of each DMU. The decision variables are $\mathrm{u}$, the vector of weights of the outputs $y$, and $\mathrm{v}$, the vector of weights of the inputs $\mathrm{x}$. The choice of intervals that restrict the weights $\mathrm{u}$ and $\mathrm{v}$ is a subject of current research and it constitutes object of interest of this work.

The first DEA formulation (Charnes et al., 1978), which became well known as CCR Model, supposes constant returns to scale (CRS). The also well known BCC Model (Banker et al., 1984) supposes variable return to scale (VRS). One of the purposes of a DEA formulation is establishing projections of inefficient DMU's on the efficiency border, settling down goals that turn them efficient. One way of doing that, in the so-called input-oriented models, is through the decrease of the input, keeping the output constant. Similarly, in the outputoriented models, we increase the output holding the input constant (Cooper et al., 2000).

For the purpose of comparing the efficiencies of the 34 Landline Telephone Services companies we developed two models. In the first one the inputs represent the main cost components and the outputs represent the products that generate revenue for the companies. 
Our second model deals with the evaluation of the services provided (Quality and Universality) taking into consideration the situation in two distinct instants of time: July of 1998, when the Quality and Universality goals were settled, and December $31^{\text {st }}$ of 2000 , the most recent instant for which there were data allowing the comparison of actual figures with settled goals.

In Section 2 we describe each model and in Section 3 we address the issue of imposing constraints on the values of the decision variables. In Section 4 we present our results and in Section 5 we develop a simulation on the consequences of two possible merges. Finally, we close with Section 6 where we present our final remarks.

\section{The Models}

\subsection{Model 1}

In this model the inputs represent the main cost components and the outputs represent the products that generate revenue for the companies. The variables we use are the following:

Inputs:

- $\mathbf{L}$ - Labor (or, number of regular employees + subcontracts): represents the largest cost component.

- PT - Number of Public Telephones Installed: relates to the investment on both, the installation and the maintenance of public phones.

- $\quad$ AI - Number of Fixed Accesses Installed: same as above for non-public phones.

Outputs:

- $\mathbf{M N}$ - Number of charged minutes in national connections: according to ANATEL, it is the first revenue indicator.

- $\mathbf{P}$ - Number of local pulse: second revenue indicator.

- AS - Number of Fixed Accesses in Service: it produces a monthly account subscription fee plus installation costs covered by the user.

The data were supplied by ANATEL and refers to the situation observed on December $31^{\text {st }}$, 2000 (see Table 1A, Appendix).

Since the discretionary variable is Labor, we will use an input-oriented formulation. We use a BCC and a CCR model in order to compute both, the technical and global efficiencies, respectively. We also compute the $\mathrm{CCR}$ and $\mathrm{BCC}$ efficiencies ratio, or scale efficiency. Then, we analyze the companies in terms of their relative size for the business and their competence in managing internal resources.

\subsection{Model 2}

The objective of Model 2 is to put in perspective the results obtained by each DMU with respect to Quality and Universality goals under the light of the amount invested and revenue level achieved by the DMU. 
Inputs:

$$
\mathrm{X} 1=(4 \mathrm{MN}+\mathrm{P}) / \mathrm{L}
$$

In the numerator of the ratio we have a revenue indicator (the average revenue per minute in national connection is four times the same for local connections) and in the denominator we have a cost indicator. Companies with greater X1 values achieve higher profit levels and thus they have greater potential of investing in Quality and Universality.

$$
\mathrm{X} 2=\mathrm{AS} / \mathrm{AI}
$$

Revenue is proportional to the number of fixed accesses in service (AS), whereas cost is proportional to the number of fixed accesses installed (AI). Thus, the $\mathrm{X} 2$ ratio is an indicator of the quality of the investments of each company.

Outputs:

As we have seen, AI and PT (number of public telephones installed) data refer to December $31^{\text {st }}$ of the year 2000. Now, let $\mathrm{AI}_{98}$ be the same as $\mathrm{AI}$ and let $\mathrm{PT}_{98}$ be the same as PT but now both measured in July of 1998, when Quality and Universality goals were settled by ANATEL. Let us also consider, as in Milioni's AHP formulation (Milioni, 2001-a), that the improvement on the number of fixed accesses and public telephones are equally important for ANATEL. Then, our first output, defined as an indicator of Universality, will be:

$$
\mathrm{Y} 1=\left[\left(\mathrm{Al}-\mathrm{Al}_{98}\right) / \mathrm{Al}_{98}\right]+\left[\left(\mathrm{PT}-\mathrm{PT}_{98}\right) / \mathrm{PT}_{98}\right]
$$

i.e., Y1 is the sum of the relative increase on the number of fixed accesses and public telephones installed in December of 2000 with respect to July of 1998, when the goals were settled by ANATEL. Data on $\mathrm{AI}_{98}$ and $\mathrm{PT}_{98}$ can be found on Table $3 \mathrm{~A}$ in the Appendix.

Output 2 is a measure of Quality improvement. Five indicators were chosen to compose output 2: Number of Repair Request per 100 accesses (RR); Number of Repair Request per 100 Public Telephones (RP); Invoice account error per 1000 invoices (IE); Relative Frequency of Local Completed Calls (LC) and Level of Digitalization (DL). For the establishment of each one of them, the following procedure was adopted: We first compute the difference among the value of the indicator for each DMU in December of 2000 and in July of 1998. Then we compute the average of all those values. Next we compute the reason between the value obtained for each DMU and the overall average. The final result is a weighted sum of the five ratios computed as above. We considered the same relative weights as in Milioni's AHP formulation (Milioni, 2001-a), i.e.: 10\% for RR, 20\% for RP, $20 \%$ for IE, $20 \%$ for LC and $30 \%$ for DL. Thus, Output 2 becomes:

$$
\mathrm{Y} 2=0.1 \frac{\mathrm{RR}_{\mathrm{o}}}{\mathrm{RR}_{\mathrm{m}}}+0.2 \frac{\mathrm{RP}_{\mathrm{o}}}{\mathrm{RP}_{\mathrm{m}}}+0.2 \frac{\mathrm{IE}_{\mathrm{o}}}{\mathrm{IE}_{\mathrm{m}}}+0.2 \frac{\mathrm{LC}_{\mathrm{o}}}{\mathrm{LC}_{\mathrm{m}}}+0.3 \frac{\mathrm{DL}_{\mathrm{o}}}{\mathrm{DL}_{\mathrm{m}}}
$$

Subscript zero represents the result associated to the DMU under analysis and subscript $m$ represents the average value of referred indicator for all DMU's.

We choose an output-oriented BCC model since we have normalized data and we want to analyze the companies for the results and possibilities of improvements related to Quality and Universality criteria and not for the resources they use to reach their results. 


\section{Restrictions on virtual inputs and outputs}

The concept of virtual input (output), defined as the product of the value of the input (output) and its respective weight was created in order to make possible the verification of the relative share of each input or output in the objective function.

Specialists arbitrarily establish the range of share of each input (output) in the objective function by choosing the constants $\varphi_{\mathrm{r}}$ e $\psi_{\mathrm{r}}$ (Allen et al., 1997) such that:

$$
\varphi_{\mathrm{r}} \leq \frac{\mathrm{u}_{\mathrm{r}} \mathrm{y}_{\mathrm{rj}}}{\sum_{\mathrm{r}=1}^{\mathrm{s}} \mathrm{u}_{\mathrm{r}} \mathrm{y}_{\mathrm{rj}}} \leq \psi_{\mathrm{r}}
$$

A variation of equation (5) is used when we want to establish an approximate interval for all DMU's through the mean value of the inputs (outputs). This way, we define general tendencies of relative share of the variable in the objective function.

$$
\varphi_{\mathrm{r}} \leq \frac{\mathrm{u}_{\mathrm{r}} \sum_{\mathrm{j}=1}^{\mathrm{N}} \mathrm{y}_{\mathrm{rj}} / \mathrm{N}}{\sum_{\mathrm{r}=1}^{\mathrm{s}} \mathrm{u}_{\mathrm{r}}\left(\sum_{\mathrm{j}=1}^{\mathrm{N}} \mathrm{y}_{\mathrm{rj}} / \mathrm{N}\right)} \leq \psi_{\mathrm{r}}
$$

In the case of three outputs we can rewrite above equation, for instance, in the following way:

$$
\varphi_{1} \leq \mathrm{u}_{1} \mathrm{MO} 1 /\left(\mathrm{u}_{1} \mathrm{MO} 1+\mathrm{u}_{2} \mathrm{MO} 2+\mathrm{u}_{3} \mathrm{MO} 3\right) \leq \psi_{1}
$$

where MOq is the average of output $\mathrm{q}, \mathrm{q}=1,2,3$.

In order to run Models 1 and 2 we used the pattern of dividing each output (input) by its respective mean value (Allen et al., 1997). Therefore, the value of MOq will be equal to 1 for all q. Let thus be the notation $u^{\prime}$ for the weight of the output divided by its mean value and $v^{\prime}$ the same for the input.

\subsection{Model 1}

Among the three inputs of Model 1, the one known to be the most relevant for the company is Labor (L). Thus, we adopted that such variable has a tendency of share in the objective function varying from $50 \%$ to $75 \%$, including the following restriction in the virtual input:

$$
0.50 \leq \mathrm{v}_{1}{ }^{\prime} /\left(\mathrm{v}_{1}{ }^{\prime}+\mathrm{v}_{2}{ }^{\prime}+\mathrm{v}_{3}{ }^{\prime}\right) \leq 0.75
$$

where the indexes 1, 2 and 3 are with respect to L, PT and AI, respectively.

Treating $\mathrm{v}_{2}{ }^{\prime}+\mathrm{v}_{3}{ }^{\prime}$ as just one variable represented by $\left(\mathrm{v}_{2}{ }^{\prime}+\mathrm{v}_{3}{ }^{\prime}\right)$ we arrived, starting from inverting the equation presented in (8) followed by a simple algebraic treatment, to the following equations, that are the constraints to be included in the model:

$$
\mathrm{v}_{1}{ }^{\prime}-\left(\mathrm{v}_{2}{ }^{\prime}+\mathrm{v}_{3}{ }^{\prime}\right) \geq 0 \quad \text { and } \quad-\mathrm{v}_{1}{ }^{\prime}+3 \cdot\left(\mathrm{v}_{2}{ }^{\prime}+\mathrm{v}_{3}{ }^{\prime}\right) \geq 0
$$

Above constraints act in the value of the weight of the variable $\mathrm{L}$ in relation to the sum of the referring weights of AI and PT. 
Now, considering that, in general, the maintenance and operation costs of a public telephone are larger than the ones of a fixed access, we arbitrate that the relationship of the share of those two variables is of 3 to 1 , i.e.:

$$
\mathrm{v}_{2}{ }^{\prime} \geq 3 \cdot \mathrm{v}_{3}{ }^{\prime}
$$

We acted in a totally similar way in the case of the outputs, considering that the main output of a company says respect to the Number of charged minutes in national connections (MN). Thus:

$0.50 \leq \frac{\mathrm{u}_{1}{ }^{\prime}}{\mathrm{u}_{1}{ }^{\prime}+\mathrm{u}_{2}{ }^{\prime}+\mathrm{u}_{3}{ }^{\prime}} \leq 0.75 \quad-\mathrm{u}_{1}{ }^{\prime}+3\left(\mathrm{u}_{2}{ }^{\prime}+\mathrm{u}_{3}{ }^{\prime}\right) \geq 0 \quad$ and $\quad \mathrm{u}_{1}{ }^{\prime}-\left(\mathrm{u}_{2}{ }^{\prime}+\mathrm{u}_{3}{ }^{\prime}\right) \geq 0$

where the indexes 1, 2 and 3 are defined with, to MN, P and AS, respectively.

We also defined, in relation to the outputs P and AS, that the relative share of the first should be 3 times greater than the one of the second. Thus,

$$
\mathrm{u}_{2}{ }^{\prime} \geq 3 \cdot \mathrm{u}_{3}{ }^{\prime}
$$

\subsection{Model 2}

In Model 2 we have two input and two output variables. Considering X1, as the most relevant variable in Model 2, we adopted as before (Model 1) that it has a tendency of share in the objective function varying from $50 \%$ to $75 \%$. Thus, we have:

$$
0.50 \leq \mathrm{u}_{1}{ }^{\prime} /\left(\mathrm{u}_{1}{ }^{\prime}+\mathrm{u}_{2}{ }^{\prime}\right) \leq 0.75
$$

where the indexes 1 and 2 are with respect to $\mathrm{X} 1$ and $\mathrm{X} 2$, respectively. From (13), we get, as before:

$$
2 \leq \frac{\mathrm{u}_{2}{ }^{\prime}}{\mathrm{u}_{1}{ }^{\prime}}+1 \leq 4 \Rightarrow 1 \leq \frac{\mathrm{u}_{2}{ }^{\prime}}{\mathrm{u}_{1}{ }^{\prime}} \leq 3 \Rightarrow-\mathrm{u}_{1}{ }^{\prime}+\mathrm{u}_{2}{ }^{\prime} \geq 0 \text { and } 3 \mathrm{u}_{1}{ }^{\prime}-\mathrm{u}_{2}{ }^{\prime} \geq 0
$$

Considering both outputs as equally important, we defined a constraint rule designed not to allow that the DEA solution has either very low or very high values for each of them. In that sense, we impose:

$$
0.30 \leq \mathrm{v}_{1}{ }^{\prime} /\left(\mathrm{v}_{1}{ }^{\prime}+\mathrm{v}_{2}{ }^{\prime}\right) \leq 0.70
$$

where the indexes 1 and 2 are with respect to $\mathrm{Y} 1$ and Y2, respectively. From (15), we get:

$$
-0.43 \mathrm{v}_{1}{ }^{\prime}+\mathrm{v}_{2}{ }^{\prime} \geq 0 \text { and } 2.33 \mathrm{v}_{1}{ }^{\prime}-\mathrm{v}_{2}{ }^{\prime} \geq 0
$$

\section{Results}

Using the software EMS (Efficiency Measurement System, version 1.3 - Aug., 2000) to run the two proposed models, we obtained the results presented in Table 1 ordered by the efficiency measured according to Model 2. 
Table 1 - Efficiency results according to Models 1 and 2 (all in \%)

\begin{tabular}{|c|c|c|c|c|c|}
\hline \multirow[b]{2}{*}{ DMU's } & \multirow[b]{2}{*}{ Companies } & \multicolumn{3}{|c|}{ Model 1} & \multirow{2}{*}{$\begin{array}{c}\text { Model } 2 \\
\\
\text { Quality \& } \\
\text { Univers. }\end{array}$} \\
\hline & & $\begin{array}{l}\text { Technical } \\
\text { Efficiency } \\
\text { (BCC) }\end{array}$ & (CCR) & $\begin{array}{c}\text { Scale } \\
\text { Efficiency } \\
(\mathrm{CCR} / \mathrm{BCC})\end{array}$ & \\
\hline 1 & Telepar & 58.5 & 50.1 & 85.7 & 100.0 \\
\hline 2 & Teleron & 52.5 & 52.5 & 99.9 & 100.0 \\
\hline 3 & Teleacre & 36.8 & 30.8 & 83.6 & 100.0 \\
\hline 4 & Ceterp & 45.2 & 45.1 & 99.6 & 100.0 \\
\hline 5 & CRT & 100.0 & 97.4 & 97.4 & 94.9 \\
\hline 6 & Telern & 76.2 & 71.1 & 93.4 & 74.0 \\
\hline 7 & Telasa & 63.5 & 63.0 & 99.3 & 66.5 \\
\hline 8 & Telepará & 74.3 & 65.0 & 87.5 & 65.6 \\
\hline 9 & CTBC Telecom MG & 53.0 & 48.9 & 92.2 & 65.2 \\
\hline 10 & Telems & 24.2 & 23.7 & 98.2 & 62.0 \\
\hline 11 & Teleamazon & 31.7 & 31.4 & 99.1 & 59.5 \\
\hline 12 & Telemat & 48.2 & 44.5 & 92.3 & 59.4 \\
\hline 13 & Telergipe & 75.4 & 74.6 & 98.8 & 59.0 \\
\hline 14 & Teleamapá & 77.4 & 69.9 & 90.4 & 57.9 \\
\hline 15 & Telaima & 54.5 & 43.9 & 80.6 & 56.0 \\
\hline 16 & Telma & 64.9 & 59.7 & 91.9 & 54.5 \\
\hline 17 & Telegoiás & 66.3 & 58.5 & 88.2 & 52.6 \\
\hline 18 & Sercomtel & 61.9 & 61.4 & 99.1 & 50.8 \\
\hline 19 & CTBC Telecom MS & 100.0 & 36.8 & 36.8 & 50.1 \\
\hline 20 & Telepisa & 44.5 & 44.3 & 99.4 & 49.3 \\
\hline 21 & Telebrasília & 55.3 & 49.3 & 89.1 & 47.4 \\
\hline 22 & CTBC Telecom SP & 100.0 & 100.0 & 100.0 & 46.6 \\
\hline 23 & CTBC Telecom GO & 85.5 & 58.9 & 68.9 & 46.2 \\
\hline 24 & Telerj & 55.5 & 45.3 & 81.6 & 45.3 \\
\hline 25 & CTMR & 55.1 & 52.1 & 94.7 & 44.6 \\
\hline 26 & Telpe & 47.4 & 41.0 & 86.7 & 43.9 \\
\hline 27 & Telesp & 100.0 & 57.0 & 57.0 & 43.6 \\
\hline 28 & Telpa & 70.3 & 65.3 & 92.9 & 42.5 \\
\hline 29 & Telest & 71.4 & 62.5 & 87.4 & 41.3 \\
\hline 30 & Telesc & 100.0 & 97.2 & 97.2 & 40.1 \\
\hline 31 & СТВСаmpo & 54.4 & 47.8 & 88.0 & 39.0 \\
\hline 32 & Teleceará & 53.6 & 45.6 & 85.1 & 30.7 \\
\hline 33 & Telemig & 66.1 & 55.2 & 83.5 & 30.4 \\
\hline 34 & Telebahia & 80.2 & 66.2 & 82.5 & 30.2 \\
\hline
\end{tabular}


In Figure 1 we plot the results obtained by Model 1 (Technical Efficiency) and Model 2.

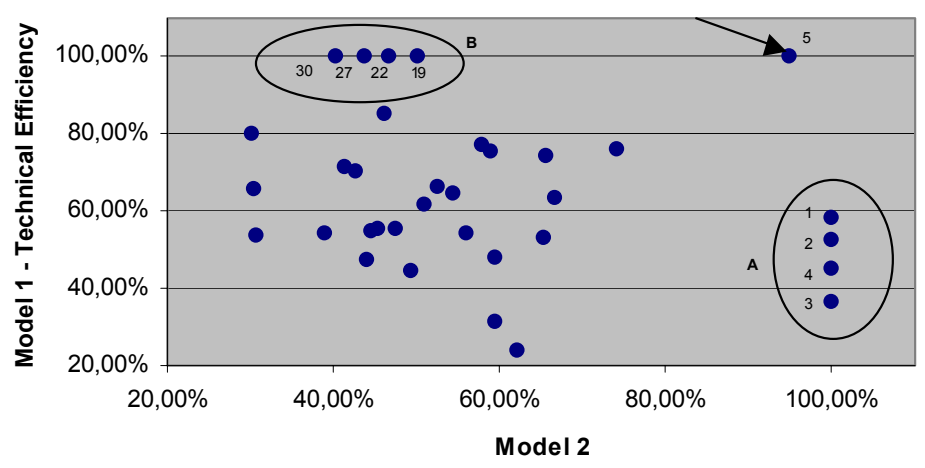

Figure 1 - Model 1 (Technical Efficiency) vs. Model 2

In Figure 1 we first observe the presence of a prominence point marked with the arrow. The company associated to the point (CRT) is a benchmark in terms of technical efficiency for Model 1 and it belongs to the set of 5 most efficient companies with respect to Quality and Universality criteria (Model 2).

Companies belonging to Cluster A (Telepar, Teleron, Ceterp e Teleacre) present low Technical Efficiency levels perhaps as a consequence of large investments on Quality and Universality, for they are benchmarks with respect to Model 2. Together with CRT, these companies are, in principle, candidates for some kind of reward from ANATEL, such as the right to explore other markets. Within the same context, companies belonging to Cluster B (CTBC Telecom MS e SP, Telesp e Telesc) would be the first addressed by ANATEL in order to explain their low performance in terms of Quality and Universality, considering that they are benchmarks in terms of Technical Efficiency regarding Model 1.

In Figure 2 we plot the results obtained by Models 1 and 2 but now considering Scale Efficiency for Model 1.

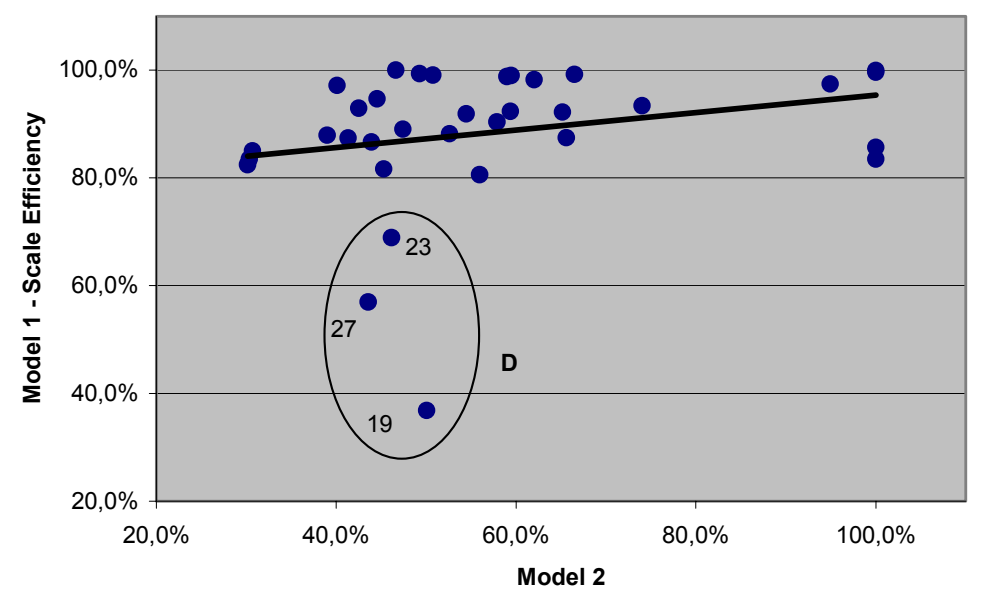

Figure 2 - Model 1 (Scale Efficiency) vs. Model 2 
The increasing tendency line shows that companies with larger Scale Efficiency tend to have larger Quality and Universality efficiencies as well, what is desirable and could be considered expected. This is an indicator that expected merges for 2003, provided they are well conducted, are likely to produce better companies overall.

Companies belonging to Cluster D (Telesp, CTBC Telecom MS and GO) show very low values for Scale Efficiency. This indicates that they are currently with wrong sizes for the business, what could be affecting their capability of achieving good Quality and Universality indicators.

Next, in Figure 3, we plot the Scale Efficiency against Technical Efficiency obtained from Model 1.

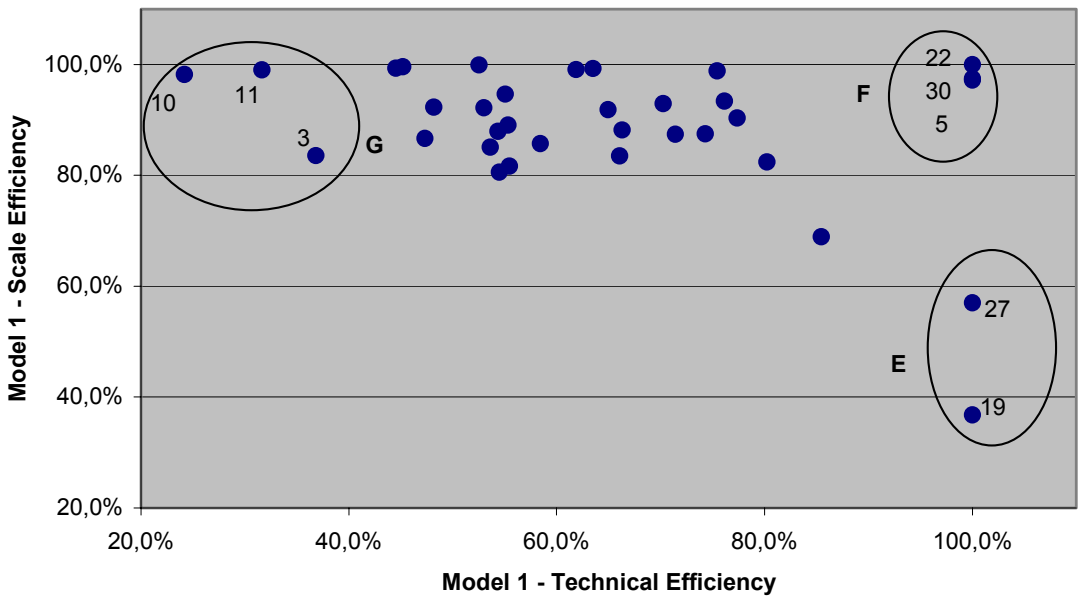

Figure 3 - Model 1: Scale Efficiency vs. Technical Efficiency

It is interesting to point out that in the study conducted by Milioni (2001-b), the 2 companies belonging to Cluster E (Telesp e CTBC Telecom MS) were considered among the best in terms of financial situation. In his work developed for ANATEL, 20 companies among the 34 studied in this article had their 2000 annual balance statement data analyzed using both, a Logit model developed by Scarpel \& Milioni (2001), and a DEA model developed by Almeida \& Milioni (2001). In none of them Scale Efficiency was taken into consideration. With our present results we can see that these two companies obtained the smallest values for Scale Efficiency, whereas achieving benchmarks in terms of Technical Efficiency. According to Cooper et al. (2000), such companies could be facing problems as a consequence of their current size or due to regional specificity.

Cluster F (CTBC Telecom SP, CRT e Telesc) represents the group of most successful companies regarding Model 1 . They all appear among top 10 in the study conducted by Milioni (2001-b) and the last 2 belong to top 5.

In the same study Milioni concluded that Teleamazon was the worst company in terms of financial figures. In our study we see that Teleamazon belongs to Cluster $\mathrm{G}$ (Teleacre, Teleamazon and Telems) which represents the group of companies with both, low Technical and low Scale efficiencies. These companies would be suggested to focus on efforts to develop theirs performance, such as reducing number of employees. 


\section{Merger Simulation}

Analyzing the results obtained in Model 1, where the companies were evaluated according to both, a CCR and a BCC formulation, we observe that CTBC Telecom MS is the company with the smallest Scale Efficiency among them all, in spite of the fact that it is a benchmark in terms of Technical Efficiency. In order to improve the Scale Efficiency of CTBC Telecom MS we propose a merger with other CTBC Telecom companies (GO, SP and MG). We will evaluate the efficiency of the new company that we will call just CTBC.

On the other hand we have Sercomtel, a company with good Scale Efficiency but Technical Efficiency below the average. For the sake of illustration we will also consider the merger of Sercomtel with Telesc, chosen according to the criteria of geographical proximity, since they are companies located in neighboring states. We will call this second company South.

Following Cooper et al. (2000), we conduct the mergers by simply adding all inputs and outputs. The data we used can be found in Table 4A, Appendix.

Next we show the efficiencies resulting from the use of the input-oriented model over the set of 30 companies resultant after the merges:

Table 2 - Efficiency results after Merger (all in \%)

\begin{tabular}{lrrc}
\hline \multicolumn{1}{c}{ DMU's } & BCC & CCR & Scale Efficiency \\
\hline CRT & 100.0 & 100.0 & 100.0 \\
South * & 100.0 & 100.0 & 100.0 \\
Telegoiás & 70.9 & 71.0 & 99.9 \\
Telebahia & 84.2 & 84.4 & 99.8 \\
Telepar & 59.4 & 59.7 & 99.6 \\
Teleceará & 59.2 & 59.6 & 99.5 \\
Telpe & 52.7 & 53.1 & 99.3 \\
Telest & 80.1 & 80.8 & 99.2 \\
Telepará & 84.4 & 85.3 & 98.9 \\
Telemig & 66.1 & 66.9 & 98.8 \\
Telerj & 55.2 & 56.0 & 98.5 \\
Telebrasília & 58.6 & 59.6 & 98.2 \\
CTBCampo & 56.9 & 58.0 & 98.1 \\
Telma & 76.7 & 78.2 & 98.1 \\
Telpa & 83.8 & 85.6 & 97.8 \\
Telern & 91.4 & 93.5 & 97.7 \\
CTBC * & 72.1 & 74.4 & 96.9 \\
Telemat & 53.4 & 55.1 & 96.8 \\
Telergipe & 96.0 & 100.0 & 96.0 \\
Telasa & 81.0 & 84.3 & 96.0 \\
Telepisa & 56.8 & 59.5 & 95.5 \\
Teleron & 67.1 & 71.0 & 94.5 \\
Teleamazon & 40.3 & 42.7 & 94.3 \\
Telems & 27.9 & 30.4 & 91.8 \\
\hline
\end{tabular}


Table 2 (cont.) - Efficiency results after Merger (all in \%)

\begin{tabular}{lrrc}
\hline \multicolumn{1}{c}{ DMU's } & BCC & CCR & Scale Efficiency \\
\hline Ceterp & 55.1 & 62.3 & 88.5 \\
Teleamapá & 86.7 & 100.0 & 86.7 \\
CTMR & 63.6 & 80.4 & 79.1 \\
Telesp & 68.0 & 100.0 & 68.0 \\
Teleacre & 39.2 & 60.7 & 64.6 \\
Telaima & 54.8 & 100.0 & 54.8 \\
\hline
\end{tabular}

* resultant from Merger

Analyzing the results presented in Table 2 we observe that the Technical Efficiency of CTBC $(72,1 \%)$ falls below the average of the former CTBC Telecom companies, which was equal to $84,6 \%$. The Scale Efficiency, however, increases to $96,9 \%$ with respect to the former average of $74,5 \%$. This results are the same as those registered by Cooper et al. (2000) in a Bank Merger Simulation, i.e., when two locally (BCC) efficient DMU's merge to form a new DMU, the new DMU is neither locally (BCC) nor globally (CCR) efficient, if increasing returns-to-scale prevails at all three DMU's.

Table 3 - CTBC's efficiency results after Merger (all in \%)

\begin{tabular}{lrrc}
\hline \multicolumn{1}{c}{ DMU's } & BCC & CCR & Scale Efficiency \\
\hline CTBC * & 72.1 & 74.4 & 96.9 \\
CTBC Telecom (MS) & 100.0 & 36.8 & 36.8 \\
CTBC Telecom (GO) & 85.5 & 58.9 & 68.9 \\
CTBC Telecom (MG) & 53.0 & 48.9 & 92.2 \\
CTBC Telecom (SP) & 100.0 & 100.0 & 100.0 \\
Average & 84.6 & 61.2 & 74.5 \\
\hline
\end{tabular}

* resultant from Merger

Results presented in Table 3 suggest that a simple Merger would not be sufficient in this case, in the sense that a reduction in the input would be also necessary in order to improve Technical Efficiency.

In the second Merge (South) the opposite was observed, since the resulting company became a benchmark both in Technical and Scale Efficiencies.

Table 4 - South's efficiency results after Merger (\%)

\begin{tabular}{lrrc}
\hline \multicolumn{1}{c}{ DMU's } & BCC & CCR & Scale Efficiency \\
\hline South $*$ & 100.0 & 100.0 & 100.0 \\
Telesc & 100.0 & 97.2 & 97.2 \\
Sercomtel & 61.9 & 61.4 & 99.1 \\
\hline
\end{tabular}

* resultant from Merger 


\section{Final Remarks}

In this work we investigated the relative efficiency of telephone companies using Data Envelopment Analysis, a tool that can be used by ANATEL as additional support in its continuous task of evaluating the performance of the companies currently providing Landline Telephone Services in Brazil. Our results enabled us to put in evidence, for instance, the companies that could be considered candidates for an eventual reward by ANATEL, such as the concession to explore other areas. We also illustrated how to estimate the potential efficiency improvement through the simulation of corporate merger.

\section{Acknowledgements}

The authors would like to present their acknowledgments to ANATEL and Fapesp, through Research Grant Number 99/10081-9.

\section{References}

(1) Allen, R.; Athanassopoulos, A.; Dyson, R.G. \& Thanassoulis, E. (1997). Weights restrictions and value judgements in Data Envelopment Analysis. Annals of Operations Research, 73, 14-25.

(2) Almeida, H.R. \& Milioni, A.Z. (2000). Análise de Envoltória de Dados na Decisão de Concessão de Crédito. Anais do XXXII SBPO - Simpósio Brasileiro de Pesquisa Operacional, Viçosa, MG, 636-649.

(3) Banker, R.D.; Charnes, A. \& Cooper, W.W. (1984). Some Models for Estimating Technical and Scale Inefficiencies in Data Envelopment Analysis. Management Science, 30, 1078-1092.

(4) Charnes, A.; Cooper, W.W. \& Rhodes, E. (1978). Measuring the efficiency of decision making units. European Journal of Operational Research, 2, 429-444.

(5) Cooper, W.W.; Seiford, L.M. \& Tone, K. (2000). Data Envelopment Analysis: A comprehensive Text with Models, Applications, References and DEA - Solver Software. Kluwer Academic, Boston.

(6) Farrel, M.J. \& Fieldhouse, M. (1962). Estimating efficient production functions under increasing returns to scale. Journal of the Royal Statistical Society, Series A, 252-267.

(7) Milioni, A.Z. (2001-a). Relatório Trimestral de Análise dos Resultados da Prestação do STFC, Período Outubro a Dezembro de 2000. Relatório Interno do Departamento de Organização (IEMB) do Instituto Tecnológico de Aeronáutica (ITA), São José dos Campos, SP.

(8) Milioni, A.Z. (2001-b). Relatório Comparativo dos Balanços das Prestadoras do STFC, Ano 2000. Relatório Interno do Departamento de Organização (IEMB) do Instituto Tecnológico de Aeronáutica (ITA), São José dos Campos, SP.

(9) Plano Geral de Metas de Qualidade para o STFC (Serviço Telefônico Fixo Comutado). Resolução No. 30 da ANATEL, 29 de Junho de 1998.

(10) Plano Geral de Metas de Universalização para o STFC (Serviço Telefônico Fixo Comutado). Decreto No. 2592 de 15 de Maio de 1998.

(11) Scarpel, R.A. \& Milioni, A.Z. (2001). Aplicação de modelagem econométrica à análise financeira de empresas. RAUSP - Revista de Administração da USP, 36, 80-88. 


\section{Appendix}

Table 1A - Model 1 Data

\begin{tabular}{|c|c|c|c|c|c|c|c|}
\hline & DMU's & $\mathbf{L}$ & PT & AI & MN & $\mathbf{P}$ & $\mathbf{A S}$ \\
\hline 1 & Telerj & 13,707 & 99,951 & $3,692,804$ & 66,715 & 898,157 & $3,348,768$ \\
\hline 2 & Telemig & 10,947 & 73,407 & $2,895,328$ & 104,585 & 650,575 & $2,746,105$ \\
\hline 3 & CTBC Telecom (MG) & 2,373 & 7,465 & 464,154 & 17,858 & 83,923 & 362,485 \\
\hline 4 & Telest & 1,837 & 16,690 & 561,042 & 25,006 & 133,454 & 503,880 \\
\hline 5 & Telebahia & 4,785 & 54,439 & $1,406,159$ & 93,584 & 289,541 & $1,302,615$ \\
\hline 6 & Telergipe & 314 & 6,776 & 170,519 & 8,366 & 32,158 & 159,206 \\
\hline 7 & Telasa & 256 & 11,681 & 251,350 & 6,268 & 45,267 & 227,226 \\
\hline 8 & Telpe & 2,821 & 41,304 & 831,171 & 33,575 & 129,859 & 714,117 \\
\hline 9 & Telpa & 686 & 13,519 & 328,803 & 16,296 & 51,858 & 293,823 \\
\hline 10 & Telern & 556 & 12,607 & 329,721 & 13,949 & 58,218 & 294,634 \\
\hline 11 & Teleceará & 3,030 & 34,874 & 791,541 & 32,330 & 170,784 & 761,737 \\
\hline 12 & Telepisa & 649 & 10,554 & 246,330 & 6,971 & 41,227 & 236,549 \\
\hline 13 & Telma & 868 & 15,296 & 321,770 & 17,600 & 58,613 & 299,971 \\
\hline 14 & Telepará & 1,050 & 23,521 & 532,904 & 20,711 & 114,351 & 513,635 \\
\hline 15 & Teleamapá & 220 & 2,055 & 71,470 & 4,379 & 12,061 & 69,287 \\
\hline 16 & Teleamazon & 1,039 & 10,420 & 315,052 & 4,470 & 47,623 & 301,052 \\
\hline 17 & Telaima & 183 & 1,602 & 48,120 & 1,898 & 7,402 & 46,024 \\
\hline 18 & Telesc & 3,461 & 25,623 & $1,193,985$ & 92,233 & 182,877 & $1,049,553$ \\
\hline 19 & Telepar & 10,659 & 46,327 & $2,227,874$ & 99,189 & 382,924 & $1,710,688$ \\
\hline 20 & Sercomtel & 851 & 2,203 & 154,499 & 7,281 & 37,475 & 139,190 \\
\hline 21 & Telems & 2,633 & 10,550 & 472,702 & 9,766 & 36,771 & 387,969 \\
\hline 22 & CTBC Telecom (MS) & 44 & 163 & 7,788 & 165 & 1,629 & 6,143 \\
\hline 23 & Telemat & 1,950 & 13,745 & 451,478 & 18,020 & 80,212 & 328,261 \\
\hline 24 & Telegoiás & 4,859 & 38,487 & $1,155,173$ & 71,272 & 226,598 & 957 \\
\hline 25 & CTBC Telecom (GO) & 86 & 588 & 30,402 & 1,194 & 4,391 & 22,076 \\
\hline 26 & Telebrasília & 3,278 & 20,175 & 884,852 & 20,617 & 199,460 & 749,120 \\
\hline 27 & Teleron & 718 & 6,345 & 253,011 & 9,766 & 36,771 & 180,469 \\
\hline 28 & Teleacre & 313 & 2,924 & 93,604 & 1,815 & 11,903 & 68,330 \\
\hline 29 & CRT & 9,731 & 53,347 & $2,101,056$ & 222,006 & 404,249 & $1,826,485$ \\
\hline 30 & CTMR & 469 & 2,015 & 120,935 & 3,492 & 23,321 & 99,406 \\
\hline 31 & Telesp & 49,550 & 223,445 & $11,185,983$ & 487,631 & $2,289,167$ & $9,413,366$ \\
\hline 32 & Ceterp & 1,307 & 3,017 & 217,837 & 6,483 & 47,654 & 184,837 \\
\hline 33 & CTBC Telecom (SP) & 374 & 2,784 & 209,829 & 10,429 & 35,251 & 164,842 \\
\hline 34 & СТВСаmpo & 5,294 & 21,577 & $1,081,897$ & 15,537 & 318,203 & 964,195 \\
\hline
\end{tabular}


Table 2A - Model 2 Data (Quality)

\begin{tabular}{|c|c|c|c|c|c|c|c|c|c|c|}
\hline & \multicolumn{5}{|c|}{$\mathrm{Jul} / 98$} & \multicolumn{5}{|c|}{ Dez/00 } \\
\hline & (TR) & (PT) & (EC) & (LC) & (TD) & (TR) & $(\mathrm{PT})$ & (EC) & (LC) & (TD) \\
\hline & $\%$ & $\%$ & $/ 1000$ & $\%$ & $\%$ & $\%$ & $\%$ & $/ 1000$ & $\%$ & $\%$ \\
\hline Telerj & 7.1 & 17.9 & 11.1 & 58.4 & 52.4 & 4.6 & 10.8 & 7.1 & 17.9 & 11.1 \\
\hline Telemig & 2.8 & 24.0 & 5.9 & 60.4 & 68.5 & 2.6 & 11.0 & 2.8 & 24.0 & 5.9 \\
\hline Telest & 2.8 & 22.0 & 9.1 & 55.7 & 77.7 & 2.6 & 10.8 & 2.8 & 22.0 & 9.1 \\
\hline Telebahia & 1.9 & 7.5 & 5.4 & 61.6 & 79.3 & 2.8 & 11.1 & 1.9 & 7.5 & 5.4 \\
\hline Telergipe & 4.7 & 34.0 & 10.0 & 46.4 & 58.9 & 2.3 & 11.7 & 4.7 & 34.0 & 10.0 \\
\hline Telasa & 4.9 & 27.0 & 4.2 & 46.6 & 60.5 & 2.4 & 10.6 & 4.9 & 27.0 & 4.2 \\
\hline Telpe & 6.2 & 33.1 & 7.6 & 53.8 & 78.0 & 4.5 & 8.4 & 6.2 & 33.1 & 7.6 \\
\hline Telpa & 6.7 & 44.5 & 5.4 & 54.5 & 73.4 & 4.5 & 10.5 & 6.7 & 44.5 & 5.4 \\
\hline Telern & 3.5 & 19.3 & 10.7 & 54.7 & 75.5 & 2.2 & 8.5 & 3.5 & 19.3 & 10.7 \\
\hline Teleceará & 3.4 & 20.2 & 11.4 & 56.8 & 75.5 & 2.2 & 8.5 & 3.4 & 20.2 & 11.4 \\
\hline Telepisa & 2.4 & 24.4 & 6.9 & 53.6 & 61.5 & 2.2 & 12.4 & 2.4 & 24.4 & 6.9 \\
\hline Telma & 4.8 & 25.3 & 6.3 & 44.4 & 87.3 & 2.8 & 8.7 & 4.8 & 25.3 & 6.3 \\
\hline Telepará & 7.0 & 19.0 & 12.8 & 47.7 & 88.3 & 3.8 & 9.9 & 7.0 & 19.0 & 12.8 \\
\hline Teleamapá & 7.2 & 22.7 & 26.3 & 45.3 & 97.0 & 2.3 & 6.7 & 7.2 & 22.7 & 26.3 \\
\hline Teleamazon & 6.8 & 12.8 & 9.0 & 41.3 & 67.7 & 2.1 & 9.6 & 6.8 & 12.8 & 9.0 \\
\hline Telaima & 3.7 & 18.7 & 5.3 & 50.0 & 72.8 & 1.4 & 6.0 & 3.7 & 18.7 & 5.3 \\
\hline CTBC Telecom MG & 1.9 & 19.0 & 8.2 & 62.8 & 53.0 & 1.9 & 8.6 & 1.9 & 19.0 & 8.2 \\
\hline Telebrasília & 2.2 & 4.1 & 6.5 & 50.4 & 69.0 & 2.6 & 8.8 & 2.2 & 4.1 & 6.5 \\
\hline CTMR & 3.1 & 34.3 & 8.7 & 56.3 & 97.5 & 1.2 & 5.4 & 3.1 & 34.3 & 8.7 \\
\hline Telesc & 3.1 & 20.0 & 3.0 & 52.3 & 88.0 & 2.1 & 7.8 & 3.1 & 20.0 & 3.0 \\
\hline Telepar & 3.0 & 28.9 & 8.7 & 62.1 & 60.3 & 2.1 & 8.6 & 3.0 & 28.9 & 8.7 \\
\hline Telems & 3.6 & 32.2 & 7.7 & 58.3 & 77.5 & 1.5 & 10.1 & 3.6 & 32.2 & 7.7 \\
\hline Telemat & 6.0 & 32.0 & 9.0 & 69.1 & 80.5 & 2.0 & 12.4 & 6.0 & 32.0 & 9.0 \\
\hline Telegoiás & 2.7 & 34.5 & 5.5 & 57.6 & 74.3 & 2.4 & 13.0 & 2.7 & 34.5 & 5.5 \\
\hline Teleron & 5.1 & 19.8 & 69.0 & 53.2 & 73.0 & 2.3 & 12.1 & 5.1 & 19.8 & 69.0 \\
\hline Teleacre & 5.5 & 26.1 & 11.5 & 54.5 & 77.4 & 2.3 & 9.6 & 5.5 & 26.1 & 11.5 \\
\hline CRT & 8.6 & 27.3 & 33.7 & 53.5 & 6.9 & 2.4 & 7.3 & 8.6 & 27.3 & 33.7 \\
\hline Sercomtel & 2.6 & 80.0 & 6.5 & 63.1 & 78.3 & 2.0 & 5.5 & 2.6 & 80.0 & 6.5 \\
\hline CTBC Telecom MS & 0.6 & 13.9 & 4.8 & 88.7 & 81.5 & 2.2 & 8.7 & 0.6 & 13.9 & 4.8 \\
\hline CTBC Telecom GO & 1.7 & 14.1 & 7.2 & 60.6 & 47.4 & 1.0 & 5.6 & 1.7 & 14.1 & 7.2 \\
\hline Telesp & 2.9 & 24.2 & 8.1 & 56.7 & 64.8 & 2.3 & 5.8 & 2.9 & 24.2 & 8.1 \\
\hline Ctbcampo & 4.3 & 8.1 & 8.0 & 65.5 & 62.2 & 1.9 & 10.1 & 4.3 & 8.1 & 8.0 \\
\hline Ceterp & 4.0 & 63.8 & 3.1 & 60.2 & 69.2 & 1.2 & 5.2 & 4.0 & 63.8 & 3.1 \\
\hline CTBC Telecom SP & 1.5 & 17.1 & 4.2 & 65.8 & 55.9 & 1.7 & 6.4 & 1.5 & 17.1 & 4.2 \\
\hline
\end{tabular}


Table 3A - Model 2 Data (Universality)

\begin{tabular}{|c|c|c|c|c|}
\hline & FA $_{98}$ & PT 98 & $\mathbf{F A}_{00}$ & PT $_{\text {00 }}$ \\
\hline Telerj & $1,927,000$ & 65,600 & $3,692,804$ & 99,951 \\
\hline Telemig & $1,811,000$ & 48,825 & $2,895,328$ & 73,407 \\
\hline CTBC Telecom (MG) & 273,643 & 4,427 & 464,154 & 7,465 \\
\hline Telest & 292,283 & 9,880 & 561,042 & 16,690 \\
\hline Telebahia & 819,395 & 32,200 & $1,406,159$ & 54,439 \\
\hline Telergipe & 93,879 & 3,295 & 170,519 & 6,776 \\
\hline Telasa & 136,798 & 4,142 & 251,350 & 11,681 \\
\hline Telpe & 411,043 & 26,327 & 831,171 & 41,304 \\
\hline Telpa & 202,252 & 7,959 & 328,803 & 13,519 \\
\hline Telern & 124,174 & 4,792 & 329,721 & 12,607 \\
\hline Teleceará & 534,098 & 22,000 & 791,541 & 34,874 \\
\hline Telepisa & 133,886 & 4,975 & 246,330 & 10,554 \\
\hline Telma & 182,781 & 6,381 & 321,770 & 15,296 \\
\hline Telepará & 266,179 & 8,679 & 532,904 & 23,521 \\
\hline Teleamapá & 40,216 & 910 & 71,470 & 2,055 \\
\hline Teleamazon & 157,118 & 4,880 & 315,052 & 10,420 \\
\hline Telaima & 28,633 & 722 & 48,120 & 1,602 \\
\hline Telesc & 609,716 & 15,360 & $1,193,985$ & 25,623 \\
\hline Telepar & $1,029,415$ & 27,596 & $2,227,874$ & 46,327 \\
\hline Sercomtel & 110,837 & 1,372 & 154,499 & 2,203 \\
\hline Telems & 233,875 & 5,400 & 472,702 & 10,550 \\
\hline CTBC Telecom (MS) & 4,787 & 53 & 7,788 & 163 \\
\hline Telemat & 231,031 & 8,617 & 451,478 & 13,745 \\
\hline Telegoiás & 542,197 & 19,200 & $1,155,173$ & 38,487 \\
\hline CTBC Telecom (GO) & 15,045 & 372 & 30,402 & 588 \\
\hline Telebrasília & 566,511 & 8,263 & 884,852 & 20,175 \\
\hline Teleron & 82,125 & 2,668 & 253,011 & 6,345 \\
\hline Teleacre & 36,000 & 753 & 93,604 & 2,924 \\
\hline CRT & $1,194,000$ & 32,552 & $2,101,056$ & 53,347 \\
\hline CTMR & 79,951 & 1,287 & 120,935 & 2,015 \\
\hline Telesp & $5,294,217$ & 156,599 & $11,185,983$ & 223,445 \\
\hline Ceterp & 154,600 & 1,924 & 217,837 & 3,017 \\
\hline CTBC Telecom (SP) & 105,761 & 1,337 & 209,829 & 2,784 \\
\hline CTBCampo & 563,024 & 13,959 & $1,081,897$ & 21,577 \\
\hline
\end{tabular}


Table 4A - Data of 30 Companies after Merger

\begin{tabular}{lrrrrrr}
\hline & $\mathbf{L}$ & \multicolumn{1}{c}{ PT } & \multicolumn{1}{c}{ AI } & \multicolumn{1}{c}{ MN } & \multicolumn{1}{c}{ P } & \multicolumn{1}{c}{ AS } \\
\hline Telerj & 13,707 & 99,951 & $3,692,804$ & $3,348,768$ & 66,715 & 898,157 \\
Telemig & 10,947 & 73,407 & $2,895,328$ & $2,746,105$ & 104,585 & 650,575 \\
Telest & 1,837 & 16,690 & 561,042 & 503,880 & 25,006 & 133,454 \\
Telebahia & 4,785 & 54,439 & $1,406,159$ & $1,302,615$ & 93,584 & 289,541 \\
Telegirpe & 314 & 6,776 & 170,519 & 159,206 & 8,366 & 32,158 \\
Telasa & 256 & 11,681 & 251,350 & 227,226 & 6,268 & 45,267 \\
Telpe & 2,821 & 41,304 & 831,171 & 714,117 & 33,575 & 129,859 \\
Telpa & 686 & 13,519 & 328,803 & 293,823 & 16,296 & 51,858 \\
Telern & 556 & 12,607 & 329,721 & 294,634 & 13,949 & 58,218 \\
Teleceará & 3,030 & 34,874 & 791,541 & 761,737 & 32,330 & 170,784 \\
Telepisa & 649 & 10,554 & 246,330 & 236,549 & 6,971 & 41,227 \\
Telma & 868 & 15,296 & 321,770 & 299,971 & 17,600 & 58,613 \\
Telepará & 1,050 & 23,521 & 532,904 & 513,635 & 20,711 & 114,351 \\
Teleamapá & 220 & 2,055 & 71,470 & 69,287 & 4,379 & 12,061 \\
Teleamazon & 1,039 & 10,420 & 315,052 & 301,052 & 4,470 & 47,623 \\
Telaima & 183 & 1,602 & 48,120 & 46,024 & 1,898 & 7,402 \\
Telepar & 10,659 & 46,327 & $2,227,874$ & $1,710,688$ & 99,189 & 382,924 \\
Telems & 2,633 & 10,550 & 472,702 & 387,969 & 9,766 & 36,771 \\
Telemat & 1,950 & 13,745 & 451,478 & 328,261 & 18,020 & 80,212 \\
Telegoiás & 4,859 & 38,487 & $1,155,173$ & 957,000 & 71,272 & 226,598 \\
Telebrasília & 3,278 & 20,175 & 884,852 & 749,120 & 20,617 & 199,460 \\
Teleron & 718 & 6,345 & 253,011 & 180,469 & 9,766 & 36,771 \\
Teleacre & 313 & 2,924 & 93,604 & 68,330 & 1,815 & 11,903 \\
CRT & 9,731 & 53,347 & $2,101,056$ & $1,826,485$ & 222,006 & 404,249 \\
CTMR & 469 & 2,015 & 120,935 & 99,406 & 3,492 & 23,321 \\
Telesp & 49,550 & 223,445 & $11,185,983$ & $9,413,366$ & 487,631 & $2,289,167$ \\
Ceterp & 1,307 & 3,017 & 217,837 & 184,837 & 6,483 & 47,654 \\
Ctbcampo & 5,294 & 21,577 & $1,081,897$ & 964,195 & 15,537 & 318,203 \\
CTBC & 2,877 & 11,000 & 712,173 & 555,546 & 29,646 & 125,194 \\
South & 4,312 & 27,826 & $1,348,484$ & $1,188,743$ & 99,514 & 220,352 \\
\hline & & & & & &
\end{tabular}

